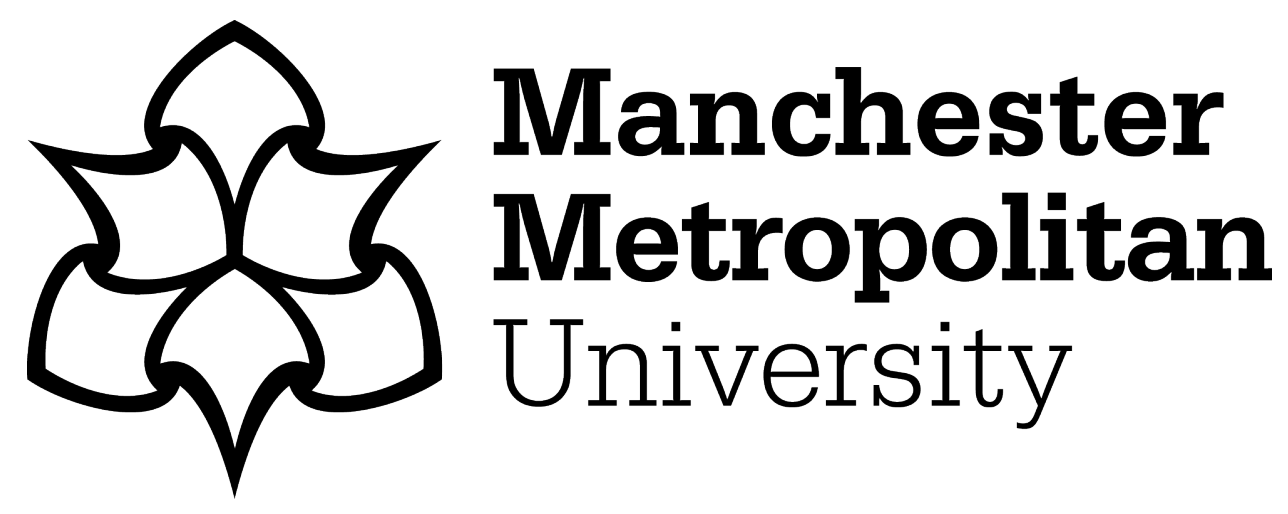

Rowley, J ORCID logoORCID: https://orcid.org/0000-0003-3437-6914 and Hanna, S (2020) Branding destinations: symbolic and narrative representations and co-branding. Journal of Brand Management, 27 (3). pp. 328-338. ISSN 1350-231X

Downloaded from: https://e-space.mmu.ac.uk/625010/

Version: Accepted Version

Publisher: Springer

DOI: https://doi.org/10.1057/s41262-019-00180-8

Please cite the published version 


\title{
Branding destinations: symbolic and narrative representations and co-branding
}

\begin{abstract}
This article explores the presence of symbolic and narrative representations on destination websites, and the explicit presence of co-branding in the form of partner logos. In contrast to previous research that tends to focus on case-studies, this article adopts a survey approach. The study undertakes a content analysis of the websites of the eighty-two destinations identified on the VisitBritain website, including cities, regions, towns, villages, and islands. On these websites there is strong evidence of symbolic branding in the form of logos. However, less than half have a clear brand narrative in the form of a slogan. In addition, less than half exhibit some form of explicit co-branding, and where co-branding is evident it is often limited to development agencies of the city or county council. Furthermore, most villages, towns and small islands lack a brand narrative and do not engage in co-branding. Accordingly, whilst destinations do have a website and a logo there is a deficit with regard to brand narratives and co-branding.
\end{abstract}

Keywords: Place brand web; place branding; place architecture; co-branding; Britain; United Kingdom

\section{Introduction}

There is widespread acknowledgement of the importance of destination branding. According to Gertner (2011, p. 1), place branding has evolved rapidly as a research domain, such that 'place branding is now a well-established concept and part of the political agenda in most cities, regions and countries' (Freire, 2016. p.78). Interest in place and destination branding is driven by competition for tourists, investment, businesses, and well-educated residents (Zenker et al., 2017). A strong and effectively communicated brand identity can attract tourists and investors, leading to economic growth and prosperity (Cleave et al., 2016). Accordingly, there is an expectation that destination management organisations (DMO's) and other policy makers should invest in and develop place and/or destination brand strategies in order to support the identification with, and positive attitudes towards the place amongst its various stakeholder groups (Braun, 2012; Anholt, 2014). This interest in branding is particularly strong in the tourism and hospitality sectors, where destinations see themselves as being in competition for tourist revenues (e.g. Truong et al., 2018).

However, despite this increased interest in destination branding, the majority of studies focus on one or a few destinations (e.g. Verucchio (Italy), in Rabbiosi, 2016; Shanghai, in Larsen, 2018; and, European capitals, in De Rosae et al., 2019), that are usually nations, cities or regions. Over a decade ago, Hanna and Rowley (2008) pointed to the dearth of research into the branding of towns and villages, yet with only a few studies in the intervening years (Fan, 2014; Ntounis and Kavaratzis, 2017; Jimenez-Esquinas and Sanchez-Carretero, 2018), there remains a significant gap in knowledge relating to the branding of towns and villages. In addition, no previous studies have surveyed the branding practices of a range of types of destination entities. 
There is also widespread acknowledgement that places do not 'stand-alone'. Places are associated with other places in their regions and with organisations, such as museums, sport teams, and businesses (Hanna and Rowley, 2015). Early research by Anholt (2004) and Hankinson (2005) argues that places should have an identified brand architecture that embraces a portfolio of brands associated with a place. In support of this, Keller (2015, p. 702) asserts 'that it is virtually impossible to manage and maximise the value and equity of a brand without a clear compelling brand architecture strategy'. In other words, Anholt (2004), Hankinson (2005) and Keller (2015) all suggest that co-branding amongst brands associated with the place is an important component of place branding. While some have argued for the application of brand architecture in its traditional sense (e.g. 'branded-house', in Zenker and Braun, 2017), due to the independence and the difficulty of exerting control over potential partner brands, others argue for a more fluid conceptualisation of co-branding (e.g. place brand webs, in Hanna and Rowley, 2015; network brands, in Aurelli and Forlani, 2016).

In conclusion, this study seeks to address the absence of previous studies that examine the extent and nature of destination branding across a range of different types of destinations. More specifically, the aim of this study is to profile the extent and nature of engagement with branding across a range of different types of UK destinations. The objectives of this study are to:

- Investigate the extent to which UK destinations are engaging in online branding at a symbolic and narrative level; and,

- Profile the extent and nature of co-branding between the brands associated with specific UK destinations.

\section{Literature Review}

\section{Destination branding}

Developing a strong, unique and favourable brand can make a significant contribution to a place or destination's competitive advantage. Increases in inter-place competition for investment, tourists and skilled workers have prompted considerable development in the practice and theory associated with place and destination branding (Papadopoulos, 2004; Hanna and Rowley, 2008; Gertner, 2011; Zenker et al., 2017), such that place and destination branding are now well-established concepts with associated practices. In addition, Cleave et al (2016) suggest that a strong brand identity that is effectively communicated can attract tourists and investors, leading to economic growth and prosperity.

Whilst the focus of this article is on destination branding, this research acknowledges the close relationship between the concepts of place and destination branding, and since we regard 'place' as the more generic concept, this article refers to both destination and place branding. We adopt Zenker and Braun's (2010, p. 5)'s definition of a place brand as 'a network of associations in the consumers' mind based on the visual, verbal, and behavioural expression of a place, which is embodied through the aims, communication, values, and the general culture of the place's stakeholders and overall place design'.

Notwithstanding interest in place and destination branding, most studies focus on 'larger' place entities such as nations, regions and cities. For example, studies focussing on cities include: Braun (2012), Trueman et al (2012), Larsen (2018), Zenker and Braun (2017), and, 
De Rosa et al (2019). Studies focussing on countries or nations include: Papadopoulos and Heslop (2007), Therkelsen and Halkier (2008), and Tasci and Denizci (2012); and those focussing on regions (often rural regions) include: Cai (2002), Haven-Tang and Sedgley (2014), and, Dinnie (2018).

On the other hand, studies on the destination branding practices of towns and villages are scarce, with three exceptions. Jimenez-Esquinas and Sanchez-Carretero (2018) analysed the discourse and practices employed to commoditise place names and to study the strategies associated with place branding. Two strategies were employed: the creation of a name to refer to a whole area, 'Casa da Morte', and the name branding of two of the better-known coastal villages. Ntounis and Kavaratzis (2017) explored the high street re-branding processes in three UK towns. On the basis of a five-stage place branding process, the importance of research, the challenges of participation and the role of communications in place branding processes were identified as primary issues for all towns. Finally, Fan (2014) reports on a branding project in Shouxian Tofu Village in China. A four-stage model including the stages of Discover, Refine, Re-design and Deliver was used to structure the project, but the success of the project was significantly compromised by interference from the local government.

Given that the existing knowledge base is dominated by studies on individual destinations and places, focusing on cities, nations, or regions, this research seeks to adopt a wider perspective by surveying the evidence of branding across a large group of destinations of various types and sizes.

\section{Symbolic and narrative representations}

Both symbols, in the form of logos, and narratives, in the form of slogans, taglines and brand names are important in communicating the essence of a destination (Munar, 2011). The symbolic approach to branding aligns with traditional approaches to branding that regard brands as static entities that are associated with one-way communication (Kladou et al., 2017). Logos are a key and very widely used element of the symbolic approach. They are used to represent and identify destinations on a range of platforms, including brochures and websites. Logos lend authority to a source of information or a communication (Florek et al., 2006).

Narratives tell a story, or, in many instances a number of different stories regarding the destination; they are dynamic and multi-facetted. For example, Hansen (2010) suggests that Bornholm in Denmark has four narratives, holiday, identity, depression, and green, whilst Van Assche and Lo (2011) investigate and compare the planning narratives in Tuscany, Minnesota and Missouri. Such narratives can be captured and communicated succinctly in slogans and taglines, which are important branding elements (Kladou et al., 2017). This research contributes by exploring the adoption of symbolic and narrative representations across a number of places of different types but does not endeavour to undertake a more comprehensive analysis of the extended narratives on the destination websites.

\section{Brand architecture and co-branding}

The concepts of brand architecture and co-branding explore the nature of the relationships between brands. Traditional branding theory views these relationships from the perspective of a number of brands, all being owned and largely controlled by the same organisation, such that together the brands form the organisation's brand portfolio (Sanchez, 2004). Brand architecture is often hierarchical, with some brands being viewed as subordinate to, or sub-brands of, other 
brands (Kapferer, 2012). A brand portfolio may be managed through either a house-of-brands or branded-house strategy, giving different levels of autonomy to the brands in the portfolio, and, for the organisation, flexibility in the use and development of brands (Aaker and Joachimsthaler, 2000; Hsu et al., 2016). Datzira-Masip and Poluzzi (2014) adopt this approach when they suggest that the Balearic Islands use the house-of-brands model since the individual islands such as Majorca are more visible than the brand of the Archipelago, whereas the Maldives use the branded-house approach since the names and characteristics of the single islands are unrecognised, but the generic characteristics of the Maldives are well known. More recently, Zenker and Braun (2017) point to the complexity of city branding and offer some insights into the use of a branded-house strategy for place brand management. However, this traditional approach implies a certain level of control over branding strategy and activities, which is often absent in the context of destination branding. The difficulty in managing a network of relationships between the brands associated with a destination is compounded by the interactive and evolutionary nature of destination brand architectures, and the complex interaction of past and present factors (Douglas and Craig, 2001; Freire, 2016; Van der Zee et al., 2017; Kotsi et al., 2018), and the political processes associated with governance (Eshuis et al., 2013; Freire, 2016). It is evident, however, that the issue of control and authority is pivotal to the establishment of an ongoing relationship between the brands associated with a place.

Given the unique characteristics of place branding, the more fluid models of brand relationships that have been developed to aid understanding of corporate co-branding may be more applicable than traditional models of brand architecture. For instance, the 'corporate brand association base' (Uggla, 2006) links the corporate brand with its surrounding environment through partner associations. For place brands, such partner associations may include other places or service brands, persons with strong associations with a place and institutional cultural associations. In co-branding, relationships are consensual and involve a shared commitment to various aspects of the brand, including its symbolic and narrative representations. According to Aarstad et al (2015), co-branding has two potential consequences. First, a transfer effect occurs when positive attributes of one brand are transferred to the other brand. Secondly, a spill over effect occurs when co-branding creates positive attitudes towards the two individual partner brands. Recent studies in the hotel sector (Tasci and Denizci, 2010; Tasci and Guillet, 2011; Dioko and So, 2012) reveal that both synergies and spill over effects can be realized through destination co-branding, however, the factors promoting such co-branding are largely unexplored (Aarstad et al., 2015). In this study, the extent of co-branding in the form of hosting the logos of other organisations, and the logos and narratives of other places associated with the destination on the destination website is explored.

\section{Methodology}

To explore the branding of an assortment of destinations in different locations in the UK and any articulated links between these brands, a content analysis of the web presence of a number of destination brands was performed. Use of the Internet was deemed pertinent as it:

- is an important medium through which people encounter destination marketing and branding, and has a significant impact on tourist decision-making (No and Kim, 2015; Rodriguez-Molina et al., 2015), 
- offers easy identification of the various destination brand representations and the links between them, and,

- facilitates comparisons between a relatively large number of destinations.

Many researchers have used content analysis of websites and social media representations of destinations (e.g. Trueman et al., 2012; Hanna and Rowley, 2015; Aurelli and Forlani, 2016) as a basis for investigating destination branding practices. Tourism is considered to be an intrinsically information-based phenomenon, such that the Internet is widely used for communication with online tourism sources (Gursoy et al., 2014). Indeed, the design of a tourism information website can affect the destination image that the tourist creates (Rodriguez-Molina et al., 2015), and DMO-branded media, such as guidebooks and websites are the strongest predictors of visitation behaviours (Morosan, 2015).

In relation to content analysis, this research adopted a broad qualitative approach that aligned with Holsti (1969, p. 14)'s definition of content analysis '...[as] any technique for making inferences by objectively and systematically identifying specified characteristic of messages'. More specifically, content analysis is an observational method used to systematically evaluate all forms of symbolic content in recorded communications, which is unobtrusive and offers an empirical starting point (Kolbe and Burnett, 1991). Consistent with the approach adopted by Lee et al (2006), the content analysis conducted in this research included the symbolic and narrative aspects of branding, including the existence of logos, and the nature of brand slogans on the place brand websites. This research does not delve in-depth into the full text on the websites. Rather it examines the websites for the presence of logos including both the place's own logo, and that of any co-brand logos, and the text of the brand slogans. Further, as would be expected of a quantitative approach, this research does not undertake counting of elements of the text or other website content. Both researchers worked in tandem in the content analysis process to ensure that they had identified the appropriate website for the analysis, and that in scanning the website, they had idenitified all of the logos and narrative statements that were deemed relevant for this study.

Given the study's objectives, there are two important decisions relating to the application of content analysis. The first is the selection of the destination websites for inclusion in the study. This study took the VisitBritain website (www.visitbritain.com), 'The official tourism website of Great Britain', as its point of departure. The website offers information on destinations, things to do, planning a trip and the opportunity to buy tickets and engage in its social media communities including Facebook, Instagram, Flickr, Twitter, YouTube and Plus Google. The 'destinations' tab leads to a list of destinations, organised by country, including England, Scotland, Wales and Northern Ireland. For each country, a number of destinations are listed. For Scotland, Wales and Northern Ireland, the list is a straight alphabetical list, but for England, destinations are first clustered into the following regions, Northern England, Central England, Southwest, and Southeast; specific destinations are listed within these regions. Hence, the VisitBritain website presents an assortment of destinations within Britain, at the country and destination level.

There are two advantages to using the VisitBritain list of destinations. First, VisitBritain marketers have identified all places in their list as 'destinations', rather than simply as 'places'. Secondly, the list not only includes countries (e.g. Wales), but also regions (e.g. Pembrokeshire), cities (e.g. Cardiff), towns (e.g. St. David's), villages (e.g. Beddgelert), and islands (e.g. Channel Isles). This provides a platform for examining and comparing the 
branding of a wide range of destination entities. This study included all of the destinations identified for Scotland (9), Wales (8), Northern Ireland (3), and England (60) (see Table 2). Details, typically including a 'slogan' summarising the identity of the place, are provided for each destination on VisitBritain. For example, for Edinburgh, the identity of the place is captured in the phrase: 'The capital of Scotland makes an unforgettable impression with its historic hilly landscape atop a series of extinct volcanoes'. Conversely, the limitation of the list of destinations on VisitBritain is that it is selective. In addition, all articulations of place identities are tailored to one specific stakeholder group, visitors or tourists.

The second decision relates to the content to be examined for each destination. This decision was guided by the research objectives. The first of these related to the identification of evidence of branding for each of the destinations listed on the VisitBritain website, both on the VisitBritain website and on the website of the destination. Hence, the presence of brand logos and the actual slogans for each destination on each of these sites was recorded. The second objective centred on the evidence of co-branding between websites, in the form of brand logos of other websites (symbol level) with respect to stakeholder organisations and other related places/destinations (e.g. the VisitEngland logo on the website for Oxford).

\section{Findings}

\section{Stage 1 - Country level analysis: symbolic and narrative representations and co-branding}

This section reports on the country level analysis for Britain and its four constituent countries, Wales, Scotland, England and Northern Ireland. First, examining the existence of logos, as an indicator of symbolic branding, at the country level, all four countries had a logo on their website (e.g. Wales - a dragon; England - a Tudor-rose). As for destination brand narratives or slogans, all except England had a slogan, but it is questionable whether these slogans communicated a unique identity. For example, Scotland's slogan is 'a spirit of its own', which may relate to whisky and independence; residents may understand this, visitors may not. Northern Ireland is captured in a slogan that does not communicate a clear identity: 'Say hello to more'.

In addition to the slogans on the country websites, the VisitBritain website also offers a slogan or narrative that seeks to communicate the character of each country. However, the creation of a coherent identity for the place brand is undermined by the lack of consistency between the slogans on the country websites and on the VisitBritain website. The slogans for Wales on the two websites do share the common themes of 'legends' and 'epic', but for Scotland, the VisitBritain website focusses on 'ancient castles guard misty locks and wild deer roam heather flecked hillsides', whilst the VisitScotland website uses the line 'Scotland. A spirit of its own'. The two slogans for Northern Ireland are rather generic and different (e.g. 'Say hello to more - Country website; 'It is easy to understand why much of hit TV series, Game of Thrones, was filmed here - VisitBritain website). For England, the VisitEngland website does have an extended piece of text about England, but no 'summary narrative', and the VisitBritain slogan, apart from the explicit mention of Big Ben, is unlikely to differentiate England from other countries.

The VisitBritain website does not include any country or other destination logos on its site; the only logo that is used anywhere on the site is the VisitBritain logo. Inspection of the country website for each of the four countries shows that all countries do have a logo, and this is used 
on their respective websites, but none use the VisitBritain logo on their website. So, whilst there is evidence of branding, there is no evidence of co-branding between the VisitBritain website and the websites of the countries, Wales, Scotland, England and Northern Ireland. Table 1 summarises the findings.

\section{$<$ Insert Table 1 here $>$}

\section{Stage 2 - Destination level analysis: symbolic and narrative representations}

On the basis of the existence of logos, as a symbolic indicator of branding, most destinations $(82 \%)$ (see Table 2), do have a brand logo on their website, which suggests that even some of the smaller destinations, such as Whitby, Colchester, and Beddgelert have recognised the need for destination branding. Many of these logos are a combination of text and images, and often feature calls to action such as Visit Tenby, Visit York, Visit Derry, Experience the Peak District and Derbyshire. Examples of destinations and the images used to represent them include: Hadrians Wall - hills; Newcastle Gateshead - bridge; Whitby - boat; Norfolk - crab; Lyme Regis - fossil.

In terms of narrative representations or brand slogans, only $37 \%$ (see Table 2) of destinations include these on their website. Those places that do have slogans succeed in capturing the essence of their destination. For example, Beddgelert has the strapline ' $a$ place in the heart of Snowdonia', Cardiff is described as 'the capital city of Wales', and Pembrokeshire invites 'come in from the cold - a beautiful coastline - the land of the epic'. In Scotland, the Outer Hebrides asserts 'experience life on the edge', Glasgow suggests 'people make Glasgow', and St. Andrews is 'one of Europe's finest towns... a place of history, learning and culture. A wonderful coastal resort and a home for golf'. In England, 'Blackpool has it all', Hadrian's Wall is 'the Northern frontier of a mighty empire that once covered the known world', Manchester it the 'original modern city', Whitby is 'perfectly placed for exploring the moors', and finally, in York, 'you'll fall in love the moment that you arrive'. None of the destinations in Northern Ireland (Belfast, Londonderry or the Causeway Coast) have a brand slogan. Those destinations that do not are reliant on the text and images on their website or other sites such as the VisitBritain website to communicate the identity of the place; this is a potentially precarious strategy. On the basis of a comparison between the VisitBritain website slogans for destinations and slogans designed by the destination, it cannot be assumed that an outside organisation will capture and communicate the essence of a place. Only a very limited number of destinations have slogans that are similar on the two websites. Amongst these is Cardiff: VisitBritain - The dynamic Welsh capital has deep roots in the past; VisitCardiff - The capital city of Wales. Also, Glasgow: VisitBritain - 'Voted one of the friendliest cities in the world...'; VisitGlasgow - People make Glasgow. For other destinations, there is limited overlap. For example, both slogans for St. Andrews mention golf, and for Whitby, coast is common theme, whilst Hadrian's Wall is described as either a frontier or a fortification. At the other extreme there are inconsistencies, including: Berwick-upon-Tweed: VisitBritain - Northernmost town in England; VisitBerwick - Northumberland: an independent spirit; St Ives: VisitBritain -See Cornwall from St Ives; VisitStIves - Arty seaside retreat in Cornwall. Table 2 provides a synopsis of the findings. 


\section{Stage 3: Destination level analysis: co-branding}

Co-branding between the web of brands associated with a destination can strengthen the visibility of the destination and its brands and contribute to the communication of a stronger and more coherent brand identity and image. Co-branding typically involves some alignment of brand core values, identities, communication and articulation, as the basis for positive image transfer between the partners in the co-branding relationship (Motion et al., 2003).

Table 2 presents the number of co-branding organisations on a country-by-country basis for Wales, Scotland, Northern Ireland, and England. None of these destinations have any evidence of co-branding with other destinations (Table 2). Taking a UK-wide perspective, only $35 \%$ of the destinations evidenced co-branding with organisations, in the form of hosting the partners' logos on their websites (Table 2). Of these, only nine hosted the logo of one other organisation, typically a regional development agency (e.g. Birmingham - West Midlands Growth Company; Chester - Chester Bid). Four hosted two logos, often the local council and a tourism agency (e.g. Londonderry - Derry City and Strabane District Council, Tourism Northern Ireland; Durham - Durham County Council, Northeast England). 13 hosted three logos (e.g. Outer Hebrides - The Scottish Government, European Agricultural Fund, Scottish National Heritage; Leeds - Visit Leeds, Leeds Inspired, Leeds City Council). Cambridge, Lincoln and Liverpool have the most co-branding partners:

- Cambridge co-brand with South Cambridgeshire District Council, Cambridge City Council, Cambridgeshire County Council, Cambridge Bid, and English Historic Cities.

- Lincoln co-brands with Visit England, Lincoln Business Improvement Group, Lincolnshire Chamber of Commerce, European Union, European Regional Development Fund, England's Historic Cities and City of Lincoln Council.

- Liverpool hosts the logos of twenty-two major stakeholder partners, in both the public and private sector on its website. These include: major partners (e.g. HSBC UK, Mayoral 100 Club); official supporters (e.g. Hotel Planner, Capital FM); official education partners (e.g. University of Liverpool); city partners (e.g. Albert Dock, Echo Arena Liverpool, Merseyrail); major funding partners (e.g. Mayor of Liverpool, Liverpool City Region, Arts Council England).

Broadly, for DMO websites that co-brand, there are a number of types of organisations identified: Public sector organisations (local councils, national governments, other tourism organisations), Regional development agencies (local, national, European and international), National parks, Heritage organisations, Cultural organisations. These agencies often work together to support place and business development and often provide some form of funding or other support for place branding. With the exception of Liverpool that hosts the logos of 22 major stakeholder partners, amongst which are both public and private sector organisations, there is no other evidence of co-branding with private sector organisations. In addition, all cobranding is with organisations, and not with other destinations in their region.

\section{Discussion}

\section{Symbolic and narrative representations}

Consistent with Florek et al (2006)'s findings in their research on city council websites in New Zealand, the logo was the most popular item on the websites. Both the VisitBritain website and 
virtually all of the destinations (at country level and below) identified on the VisitBritain website engage in branding at the symbolic level. Exceptions are smaller towns, including Conwy (town), and St. Davids, and villages for example, Hay-on-Wye, and Applecross. On the other hand, this research does provide evidence that some towns, such as St. Andrews and Whitby, do engage in place branding through the use of logos. Previous research on the use of logos is limited and such studies that do exist focus on the symbolic meaning communicated by logos, rather than surveying the extent of their use (Florek et al., 2006; Kladou et al., 2017). Indeed, Kladou et al (2017) suggest that although, in general, the use of logos in branding might be considered to be crucial, the significance and impact of the brand's symbolism (including that of the logo) remains to be established, on account of the variety of images associated with a place in different contexts and by different stakeholders.

The extent to which destinations engage in narrative representation is limited. Typically, destination websites do contain information about their place and often a range of photographs and other images, but many do not communicate a succinct statement of their identity, in the form of a narrative or a slogan. For example, at country level, neither England or Northern Ireland articulate a coherent core identity. In comparison, Wales and Scotland do effectively communicate a clear identity, and, further, there is also an alignment between their VisitDestination and VisitBritain website articulations. At region and city level and below, only some destinations have a brand slogan. Moreover, where slogans were available, in most instances the slogans had very little in common on the VisitBritain and VisitDestination websites for the destination. However, slogans that are evident do provide information on a destination that is useful to tourists, in that they communicate something of the nature and essence of a place and/or point to other stakeholders in the place's network. Nevertheless, for the destination website designers in this study there is scope for further reflection on the communication of, and cultivation of engagement with the destination narratives (Hansen, 2010). In addition, other researchers (e.g. Govers and Go, 2009; Kladou et al., 2017) suggest that successful logos and slogans are only part of the picture, and that a variety of other initiatives are also necessary to engage tourists and other stakeholders with the destination's multi-facetted narrative (Kavaratzis, 2004; Assche and Lo, 2011)

Finally, this research demonstrates that many of the villages and towns that are identified as destinations on the VisitBritain website have limited engagement in destination branding. Other authors have also commented this deficit (e.g. Hanna and Rowley, 2008; Fan, 2014; Samuel et al., 2018). To address this, respectively, Fan (2014) and Ntounis and Kavaratzis (2017) propose and test destination branding models and demonstrate their application to villages, and towns. Fan (2014) suggests the 4D Place Branding Model, which incorporates the stages of Discover, Define, Design and Deliver, whilst Ntounis and Kavaratzis (2017) offer a model of the participatory branding process, with the following stages: Research, Deliberation, Consultation, Action, and Communication. Both studies emphasize the importance of participation and the engagement of stakeholders as being of particular importance in the context of towns and villages. In addition, Fan (2014) and Jimenez-Esquinas and SanchezCarretero (2018) emphasise the importance of heritage in branding and marketing villages.

\section{Brand architecture and co-branding}

Whilst none of the destinations studied have evidence of destination co-branding (Table 2, Cobranding partners), at either the symbolic or narrative level, some provide information on other 
places in their country or region, thus communicating a web of places through their website. In other words, they engage in information provision, and to some extent, marketing, of associated places. For example, Visit North Norfolk (www.visitnorthnorfolk.com) provides information on Cromer and other places in the region, but does not show any brand logos for these destinations (Table 2, England). Similarly, for example, the Cotswolds website (www.cotswolds.co.uk) provides information on, but no logo for Broadway. Furthermore, the website for Broadway (www.broadway-cotswolds.co.uk) does offer a logo for both Broadway and the Cotswolds, but the Cotswolds logo differs significantly from that shown on the Cotswolds website (Table 2, England). To take another example, the Outer Hebrides (www.visitouterhebrides.co.uk) provide a link to information on the Isle of Lewis, but no associated logo, despite there being a logo for the Ilse-of-Lewis on www.isle-of-lewis.com (Table 2, Scotland). It is argued that these examples are evidence of an 'Implicit Place Brand $W e b$ ' where there is acknowledgement of associations between a place and other places through marketing communication, but no identifiable or explicit link to co-branding.

The converse of the 'Implicit Place Brand Web' is the 'Explicit Place Brand Web', where there is evidence, on the website (or on other sources of information, such as printed documents), of a network of associated organisations and places, through the hosting of the brands of associated organisations or places (Anholt, 2002; Hankinson, 2005; Hanna and Rowley, 2015). In line with the latter, the findings provide limited evidence of co-branding between destinations and partner organisations (Table 2), including regional development agencies, business improvement groups, local, national and international government. Other research has also revealed a lack of engagement in networks or co-branding in practice. In their study of sixteen city council websites, Florek et al (2006) found that in only one case was the logo widely used as a base by other city-related organisations. Aureli and Forlani (2016) examined the extent to which network brand management is a key activity in tourism business networks. They found that whilst the network brand identity is a prerequisite for all alliances, the network brand is not always exploited for commercial purposes and often not communicated. Similarly, Van der Zee et al (2017) found that although the network approach was seen to be a promising way to make the tourism industry more innovative and competitive, tourism managers gave very little support to this approach in practice. This is consistent with findings from other studies which report on city branding efforts that are top-down endeavours with stakeholders (Braun et al., 2013; Larsen, 2018). The lack of co-branding identified in this and previous studies can arguably be attributed to the complexity of the challenges associated with communicating the multiple identities of a place (e.g. Van der Zee et al., 2017), the political tensions associated with managing a wide range of stakeholders (e.g. Zenker et al., 2017) and the level of resources available to place brand (e.g. Chekalina et al., 2018).

\section{Conclusions, Practical implications, and Limitations}

This study contributes to theory and research in destination branding by profiling the extent and nature of the branding associated with a number of places that have been identified as destinations. The study demonstrates that there is widespread acknowledgement of the importance of brand logos, but many destinations do not use narrative representations, and nor do they engage with co-branding. 
In terms of practical implications, this study finds that there has been a considerable penetration in terms of branding at the logo level, but that places and their brand managers need to 'bring the place brand identity to life'. In this process, the importance of focused and consistent brand narratives needs to be appreciated and designed to both evolve and speak to the wide diversity of stakeholder groups associated with a place. It is also important that they identify the individual or collection of attributes that differentiates them from their competitors as a basis for clearly communicating a USP and maintaining political neutrality across diverse stakeholder groups. In addition, place brand managers, especially those responsible for destination brands, need to capitalise on the potential of an effectively managed and dynamic co-branding strategy. More significantly, brand managers should seek to maximise the impact of their place brand's digital presence by capitalising on, optimising and explicitly communicating their strategic alliances, through co-branding.

Whilst this research offers important insights into the branding practices of several destinations, it is not without limitations. First, the study only examined the websites of eightytwo destinations, and secondly, the research focussed on destination or tourism websites, and did not examine place branding that is directed towards other stakeholder groups, such as residents, businesses, and students. Further research could usefully complement this study, by examining the websites of additional places, and those directed towards other stakeholder groups. A particularly interesting line of enquiry would be to explore more widely other websites associated with a place, with a view to distilling a sense of the communicated brand identity and/or narratives across all of these sites. There is also scope for addressing the paucity of studies that explore the value and role of logos and other common branding elements in communicating the identity of the place. In addition, this research adopts a traditional approach to the notion of branding. Further research could usefully explore two-way narratives about a place, as might, for instance be mediated through a DMO or other social media channel. A further limitation is the dependence on the hosting of logos of other organisations or places as evidence of co-branding. An interview-based study would have the potential to yield deeper insights into the relationships between organisations in the place's brand web, including the perceived challenges, precursors to and benefits of co-branding.

\section{Conflict of interest statement}

On behalf of all authors, the corresponding author states that there is no conflict of interest.

\section{References}

Aarstad, J. Ness, H., and Haugland, S. A. (2015) Network position and tourism firms' cobranding practice. Journal of Business Research 68(8): 1667-1677.

Anholt, S. (2002) Foreword to the special issue on place branding. Journal of Brand Management 9(4): 229-239.

Anholt, S. (2004) Foreword. Place Branding and Public Diplomacy 1(1): 4-11.

Anholt, S. (2014) Afterword. Place Branding and Public Diplomacy 10(2): 167-169. 
Assche, K. V., and Lo, M. C. (2011) Planning, preservation and place branding: a tale of sharing assets and narratives. Place Branding and Public Diplomacy 7(2): 116-126.

Aurelli, A., and Forlani, F. (2016) The importance of brand architecture in business networks: the case of tourist network contracts in Italy. Qualitative Market research: An International Journal 19(2): 133-155.

Baker, B. (2007) Destination branding for small cities: Essentials for successful place branding, Portland, Oregon: Creative Leap Books.

Braun, E. (2012) Putting city branding into practice. Journal of Brand Management 19(4): 257267.

Braun, E., Kavaratzis, M., and Zenker, S. (2013) My City- My Brand: the role of residents in place branding. Journal of Place Management and Development 6(1): 18-28.

Cai, L. (2002) Cooperative branding for rural destinations. Annals of Tourism Research 29(3): $720-742$.

Chekalina, T., Fuchs, M., and Lexhagen, M. (2018) Customer-based destination brand equity modelling: the role of destination resources, value for money, and value in use. Journal of Travel Research 57(1): 31-51.

Braun, E., and Zenker, S. (2010) Towards an integrated approach for place brand management. $50^{\text {th }}$ European Regional Science Association Congress, Jonkoping, Sweden, available at: www.sre.wu.ac.at/ersa/ersconfs/ersa10/ERSA2010finalpaper181.pdf (accessed 28/11/2018)

Chekalina, T., Fuchs, M. and Lexhagen, M. (2018) Customer-based destination brand equity modelling: The role of destination resources, value for money, and value in use. Journal of Travel Research 57(1): 31-51.

Cleave, E., Arku, G., Sadler, R., and Gilliland, J. (2016) The role of place branding in local and regional economic development: bridging the gap between policy and practicality. Regional Studies, Regional Science 3(1): 207-228.

Datzira-Masip, J., and Poluzzi, A. (2014) Brand architecture management: the case of four destinations in Catalonia. Journal of Destination Marketing and Management 3(1): 48-58.

De Rosa, A., Bocci, E. and Dryjanska, L. (2019) Social representations of the European capitals and destination e-branding via multi-channel web communication. Journal of Destination Marketing and Management 11: 150-165. 
Dinnie, K. (2018) Contingent self-definition and amorphous regions: a dynamic approach to place brand architecture. Marketing Theory 18(1): 31-53.

Dioko, L.A.N. and So, S.I. (2012) Branding destinations versus branding hotels in a gaming destination: Examining the nature and significance of co-branding effects in the case study of Macao. International Journal of Hospitality Management 31(2): 554-563.

Douglas, S., and Craig, S. (2001) Executive insights - integrating branding across markets: building international brand architecture. Journal of International Marketing 9(2): 97-114.

Eshuis, J., Braun, E., and Klijn, E-H. (2013) Place marketing as governance strategy: an assessment of obstacles in place marketing and their effects on attracting target groups. Public Administration Review 70(3): 507-516.

Fan, H. (2014) Branding a place through its historical and cultural heritage: the branding project of Tofu village in China. Place Branding and Public Diplomacy 10(4): 279-287.

Florek, M., Insch, A., and Gnoth, J. (2006) City Council websites as a means of place brand identity communication. Place Branding 2(4): 276-296.

Freire, J. R. (2016) Managing destination brand architecture - the case of Cascais Municipality. Place Branding and Public Diplomacy 12(1): 78-90.

Gertner, D. (2011) Unfolding and configuring two decades of research and publications on place marketing and place branding. Place Branding and Public Diplomacy 7(2): 91-106

Govers, R., and Go, F. (2009) Place Branding: Glocal, Virtual and Physical Identities Constructed, Imagined and Experienced. Basinstoke: Palgrave Macmillan

Gursoy, D., Chen, J. S., and Chi, C. G. (2014) Theoretical examination of destination loyalty formation. International Journal of Contemporary Hospitality Management 26(5): 809-827.

Hankinson, G. (2005) Destination brand images: a business tourism perspective. Journal of Services Marketing 19(1): 24-32.

Hankinson, G. (2007) The management of destination brands: five guiding principles based on recent development in corporate branding theory. Journal of Brand Management 14(1): 240-254.

Hanna, S., and Rowley, J. (2008) An analysis of terminology use in place branding. Place Branding and Public Diplomacy 4(1): 61-75.

Hanna, S., and Rowley, J. (2013) A practitioner-led strategic place brand management model. Journal of Marketing Management 29(15-16): 1782-1815. 
Hanna, S. and Rowley, J. (2015) Towards a model of the Place Brand Web. Tourism Management 48: 100-112.

Hansen, R. H. (2010) The narrative nature of place branding. Place Branding and Public Diplomacy 6(4): 268-279

Haven-Tang, C., and Sedgley, D. (2014) Partnership working in enhancing the destination brand of rural areas: a case study of Made in Monmouthshire, Wales, UK. Journal of Destination Marketing and Management 3(1): 59-67.

Holsti, O. R. (1969) Content analysis for the social sciences and humanities. Addison-Wesley, Reading, MA.

Hsu, L., Fournier, S., and Srinivasan, S. (2016) Brand architecture strategy and firm value: hoe leveraging, separating, and distancing the corporate brand affects risk and returns. Journal of the Academy of Marketing Science 44(2): 261-280.

Jimenez-Esquinas, G., and Sanchez-Carretero, C. (2018) Who owns the name of a place? On place branding and logics in two villages in Galicia, Spain. Tourist Studies 18(1): 3-20.

Kapferer, J-N. (2012) The New Strategic Brand Management: Advanced Insights and Strategic Thinking. London: Kogan Page.

Kavaratzis, M. (2004) From city marketing to city branding: toward a theoretical framework for developing city brands Place Branding 1(1): 58-73.

Keller, K. (2015) Designing and implementing brand architecture strategies. Journal of Brand Management 21(9): 702-715.

Kladou, S., Kavaratzis, M., Rigopoulou, I., and Salonika, E. (2017) The role of brand elements in destination branding. Journal of Destination Marketing and Management 6(4): 426-435

Kolbe, R. H., and Burnett, M. S. (1991) Content-analysis research: An examination of applications with directives for improving research reliability and objectivity. Journal of Consumer Research 18: 243-250.

Kotsi, F., Balakrishnan, M. S., Michael, I., and Ramsoy, T. Z. (2018) Place branding: aligning multiple stakeholder perception of visual and auditory communication elements. Journal of Destination Marketing and Management 7(3): 112-130.

Larsen, H. G. (2018) The 'mental typography of the Shanghai city brand: a netnographic approach to formulating city brand positioning strategies. Journal of Destination Marketing and Management 8(6): 90-101. 
Lee, G., Cai, L. A., and O’Leary, J. T. (2006) WWW.Branding.States.US: An analysis of brand-building elements in the US state tourism websites. Tourism Management 27:815828.

Morosan, C. (2015) The influence of DMO advertising on specific destination visitation behaviours. Journal of Hospitality Marketing and Management 24(1): 47-75.

Motion, J., Leitch, S., and Brodie, R. J. (2003) Equity in corporate co-branding: the case of Adidas and the All Blacks. European Journal of Marketing 37(7/8): 1080-1094.

Munar, A. M. (2011) Tourist-created content: rethinking destination branding. International Journal of Culture, Tourism and Hospitality Research 5(3): 291-305.

No, E., and Kim, J. K. (2015) Comparing the attributes of online tourism information sources. Computers in Human Behaviour 50(9): 564-575.

Ntounis, N., and Kavaratzis, M. (2017) Re-branding the High Street: the place branding process and reflections from three UK towns. Journal of Place Management and Development 10 (4): 392-403.

Papadopoulos, N., and Helsop, L. (2007) Country equity and country branding: problems and Prospects. Journal of Brand Management 9(4): 294-314.

Pryor, S., and Grossbart, S. (2007) Creating meaning on main street: towards a model of place branding. Place Branding and Public Diplomacy 3(4): 291-304.

Rabbiosi, C. (2016) Place branding performance in tourist local food shops. Annals of Tourism Research 60(9): 154-168.

Rodriguez-Molina, M. A., Frias-Jamilena, D. M., and Castaneda-Garcia, J. A. (2015) The contribution of website design to the generation of tourist destination image: the moderating effect of involvement. Tourism Management 47(4): 303-317.

Sanchez, R. (2004) Conceptual analysis of brand architecture and relationships with product categories. Journal of Brand Management 11(3): 233-247.

Tasci, A. D. A., and Denizci, R. (2010) Fashionable hospitability: a natural symbiosis for Hong Kong's tourism industry? International Journal of Hospitability Management 29(3): 488499.

Therkelsen, A., and Halkier, H. (2008) Contemplating place branding umbrellas: the case of coordinated national tourism and business promotion in Denmark. Scandinavian Journal of Hospitality and Tourism 8(2): 159-175. 
Trueman, M., Klemm, M., and Giroud, A. (2004) Can a city communicate? Bradford as the corporate brand. Corporate Communications: An International Journal 9(4): 317-330.

Trueman, M., Cornelius, N., and Wallace, J. (2012) Building brand value online: exploring relationships between company and city brands. European Journal of Marketing 46(7/8): 1013-1031.

Truong, T. L. H., Lenglet, F., and Mothe, C. (2018) Destination distinctiveness: concept measurement, and impact on tourist satisfaction. Journal of Destination Marketing and Management 8(6): 214-231.

Uggla, H. (2006) The corporate brand association base: a conceptual model for the creation of inclusive brand architecture. European Journal of Marketing 40(7/8): 785-802.

Van Assche, K., and Lo, M. (2011) Planning, preservation and place branding: a tale of sharing assets and narratives. Journal of Place Branding and Public Diplomacy 7(2): 116-126.

Van der Zee, E., Gerrets, A. M., and Vanneste, D. (2017) Complexity in the government of tourism networks: balancing between external pressure and internal expectations. Journal of Destination and Marketing Management 6(4): 296-308.

Zenker, S., Braun, E., and Petersen, S. (2017) Branding the destination versus the place: the effect of brand complexity and identification for residents and visitors. Tourism Management 58(2): 15-27.

Zenker, S., and Braun, E. (2017) Questioning a 'one size fits all' city brand: developing a branded house strategy for place brand management. Journal of Place Management and Development 10(3): 270-287. 


\begin{tabular}{|c|c|c|c|c|c|}
\hline & $\begin{array}{l}\text { Country } \\
\text { logo on VB } \\
\text { website }\end{array}$ & VB website slogan & VB logo on country website & $\begin{array}{l}\text { Country logo on } \\
\text { country website }\end{array}$ & $\begin{array}{l}\text { Visit country } \\
\text { website slogan }\end{array}$ \\
\hline : & & & $\begin{array}{l}\text { VB logo on Visit Britain } \\
\text { website - present }\end{array}$ & & \\
\hline$\frac{\frac{n}{\pi}}{\pi}$ & Not present. & $\begin{array}{l}\text { The land of legends: Wales. Immerse } \\
\text { yourself in Wales' epic story and enjoy } \\
\text { ancient scenery, action packed activities } \\
\text { and a cast of characters you'll never } \\
\text { forget. }\end{array}$ & $\begin{array}{l}\text { Not present } \\
\text { VisitWales.com } \\
\text { (No Cymru) }\end{array}$ & Dragon & $\begin{array}{l}\text { Welcome to the } \\
\text { year of legends: } \\
\text { visit our epic land. }\end{array}$ \\
\hline 焉 & Not present. & $\begin{array}{l}\text { Scotland: the year of history, heritage } \\
\text { and archaeology } \\
\text { Welcome to the land where ancient } \\
\text { castles guard misty locks and wild deer } \\
\text { room heather-flecked hillsides. }\end{array}$ & $\begin{array}{l}\text { Not present } \\
\text { VisitScotland.com } \\
\text { (Gaelic for Scotland - Alba) }\end{array}$ & Thistle & $\begin{array}{l}\text { Scotland. A spirit of } \\
\text { its own. }\end{array}$ \\
\hline 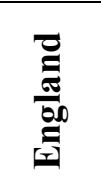 & Not present. & $\begin{array}{l}\text { Few countries inspire quite like } \\
\text { England, home to iconic landmarks such } \\
\text { as Big Ben and even bigger expanses of } \\
\text { gorgeous landscapes. }\end{array}$ & $\begin{array}{l}\text { Not present } \\
\text { VisitEngland.com }\end{array}$ & Tudor-rose & Not present. \\
\hline 吾 & Not present. & $\begin{array}{l}\text { Northern Ireland } \\
\text { it is easy to understand why much of hit } \\
\text { TV series, Game of Throne, was filmed } \\
\text { here. }\end{array}$ & $\begin{array}{l}\text { Not present } \\
\text { DiscoverNorthernIreland.com }\end{array}$ & $\begin{array}{l}\text { Pink shamrock } \\
\text { embedded in a } \\
\text { pink emerald. }\end{array}$ & Say hello to more. \\
\hline
\end{tabular}

Table 1: Summary of the findings for Stage 1 (VB denotes VisitBritian) 


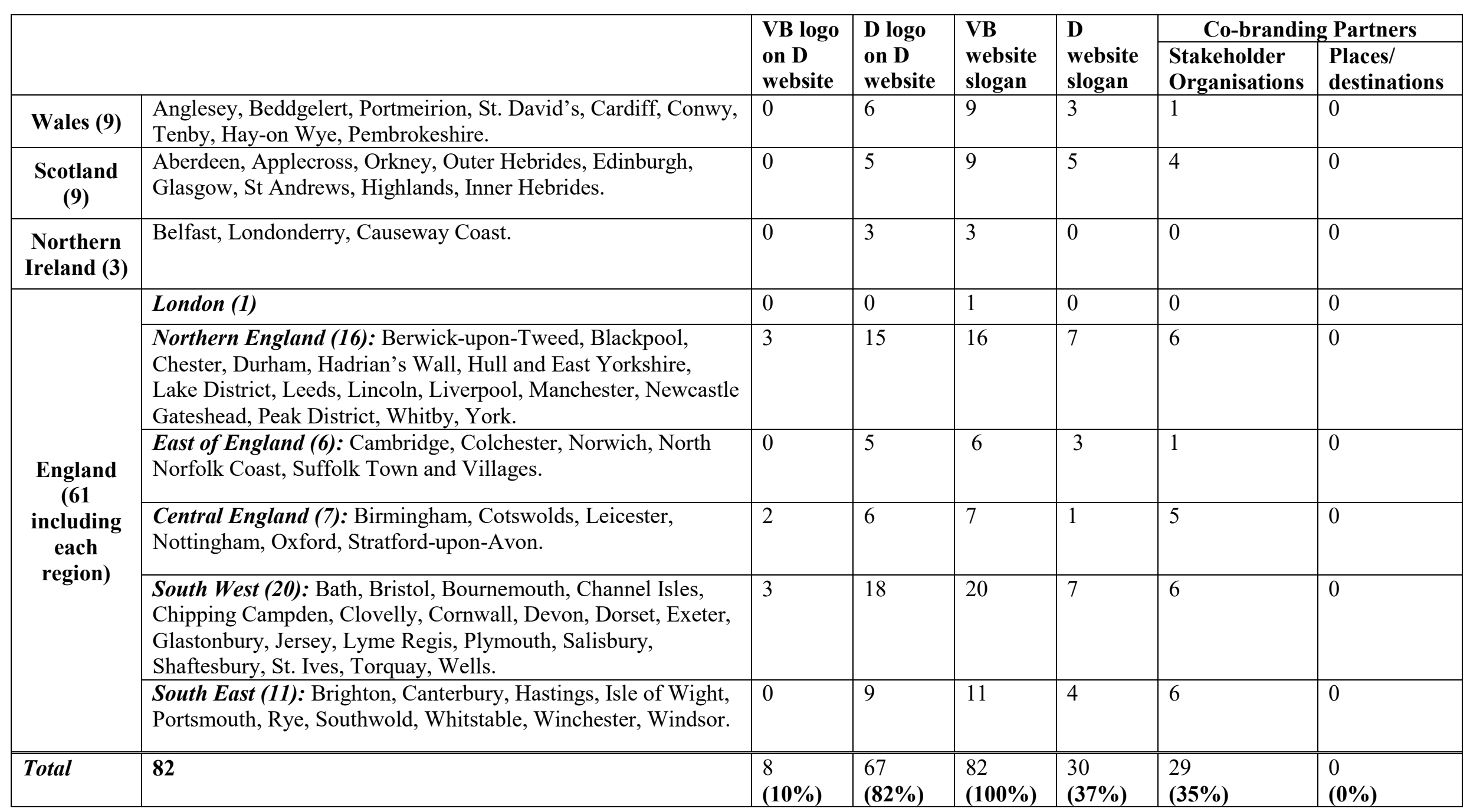

Table 2: Summary of the findings for Stages 2 and 3 (D denotes Destination; VB denotes Visit Britain) 